\title{
Anal Cancer Pathologic Primary Tumor TNM Finding v7
}

National Cancer Institute

\section{Source}

National Cancer Institute. Anal Cancer Pathologic Primary Tumor TNM Finding v7. NCI

Thesaurus. Code C90022.

A pathologic finding about one or more characteristics of anal cancer, following the rules

of the TNM AJCC V7 classification system as they pertain to staging of the primary tumor. 